\title{
NYUMBA YA MUNGU RESERVOIR SYSTEM SIMULATION BY USING HEC-RESSIM MODEL
}

\author{
${ }^{1}$ Deogratias M.M. Mulungu, ${ }^{2}$ Rejea Ng'ondya and ${ }^{3}$ Felix W. Mtalo \\ University of Dar es Salaam, \\ College of Engineering and Technology, Department of Water Resources Engineering \\ P.O Box 35131 Dar es Salaam

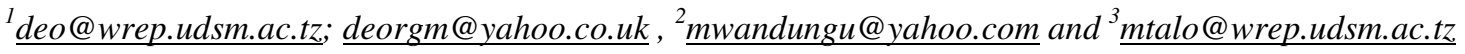

\begin{abstract}
This research paper focused on estimating effective water and optimization of the NyM reservoir for storage conservation and hydropower generation. Several models were used in the study: the Rainfall-Runoff model, GFFS was used to fill in missing data, and the HEC-ResSim Model and the NWBM for reservoir system simulation and water balance respectively. The effective inflows to the NyM reservoir were determined using HEC-ResSim model and the NWBM used to check the total water loss in the system. For the reservoir system simulation, the HEC-ResSim model was used to estimate water loss through irrigation abstractions in Kikuletwa and Ruvu reaches before water enters the NyM reservoir. The loss was estimated to be 27\% of the total inflows at 1DD1 and 1DC1 gauging stations upstream the reservoir. Reservoir evaporation was estimated using pan evaporation data collected from NyM meteorological station. The effective inflows are important data to the reservoir system simulations for power production. The mean value of effective water reaching the NyM compared well with the previous study measurement of the dry season value, which was done before the dam construction. The HEC-ResSim simulated releases were used to determine the power production at NyM hydropower plant. Considering water abstractions, the first simulated alternative favored storage conservation in the reservoir. The power achieved in this alternative was 7\% above the TANESCO production (41.6 GWh/yr). The second simulated alternative was to maximize power production at NyM hydropower plant. This alternative yielded $13 \%$ above TANESCO production. Despite the high energy attainable in maximization option, the reservoir water levels trend was seen to draw down drastically. The study also investigated the extent of the impact brought about by the abstracted water. If irrigation abstractions were restricted from the two reaches then power production would increase by 11.5 GWh. This increment is about $24 \%$ above the power produced when abstraction is allowed in Ruvu and Kikuletwa River reaches.
\end{abstract}

Keywords: firm power, HEC-ResSim model, hydroelectric power, Nyumba ya Mungu Reservoir, reservoir simulation, spillage, water abstractions

\section{INTRODUCTION}

The generation of electricity in Tanzania is mainly from both hydro and thermal power plants. The total installed capacity on the interconnected grid is about $757 \mathrm{MW}$ of which $555 \mathrm{MW}$ (73\%) is hydro and the rest is thermal. The generation from the hydropower plants is dependent on flow of water in the rivers which, undesirably, is stochastic in nature, exhibiting spatial variability as well as temporal variations (daily, seasonal, annual and over-year variations). For example, the two reservoirs at Mtera (3200 $\mathrm{Mm}^{3}$ live storage) and Nyumba ya Mungu (NyM) $\left(580 \mathrm{Mm}^{3}\right.$ of live storage) (Mhita, 2001), located upstream from the power plants are meant to regulate such variations in natural uncontrolled flows. The Tanzania Electric Supply Company Limited (TANESCO) is responsible for the generation, transmission, distribution and the selling of electricity to mainland Tanzania and the bulk power to Zanzibar. TANESCO has been faced with a severe supply shortage on the grid system, generally attributed to poor rains in the upper catchments of Ruaha and Pangani river basins. Other reasons, apart from failure of rains include high abstractions and evaporation in the hydropower systems. TANESCO has been forced also to draw more energy from hydro system due to high costs of operating thermal plants.

The Pangani River basin covers an area of about $42,000 \mathrm{~km}^{2}$, and the Pangani River drains to the Indian Ocean where it supplies freshwater to the coastal town of Pangani and the mangrove forests at the delta. Most of the water in the Pangani basin is used for irrigation and hydropower production. Up to 55,000 ha of land is under crops irrigation and there are three hydropower facilities (NyM, Hale and New Pangani Falls (NPF)) that supply up to $20 \%$ of Tanzania's electricity needs (Pabari, 2004).

NyM reservoir was built at the beginning of 1964 and began its full operation in 1968, providing supplemental regulation of water for hydropower development as well as irrigation purposes as cited by Moges (2003). It is the only reservoir on the Pangani basin, and it regulates river flows from an 
area of about $9000 \mathrm{~km}^{2}$. The reservoir acts as a buffer which permits adjustments to be made between supply in the form of inflow and demand in the form of release for hydropower development or any other purpose downstream of the reservoir system (Killingtveit and Saelthun, 1995). NyM reservoir provides a head of approximately $25 \mathrm{~m}$; the overall height is $29 \mathrm{~m}$. The reservoir has a total storage capacity of $871.5 \mathrm{Mm}^{3}$ as cited by Moges (2003). A hydro plant is built just adjacent to the dam which has a capacity of $8.2 \mathrm{MW}$. The plant has two units each producing 4.1 MW as cited by Kigadye (2000). Downstream the reservoir, there are two operational hydro plant the first is Hale station (21 MW), located at Hale town and the second one is called NPF (66 MW), which is located just downstream the Hale station. The operations in the two hydro plants is mainly depending on the releases from NyM reservoir.

Global climate change has reduced the ice-cap on Kilimanjaro, one of the principal sources for the Pangani River while deforestation has compromised the region's ability to retain water. These reductions in supply, coupled with increasing water demands for irrigation and hydropower generation have led to considerable conflicts over the allocation and use of water in Pangani basin. Conflicts are varied and range from: disagreement with the commercialization of water, disputes over water allocation between upstream and downstream users, disputes over allocation between agriculture and hydropower, disputes between agriculturalists and pastoralists.

The purpose of this study was to apply the physically distributed model, HEC-ResSim to estimate the effective inflow to the reservoir and simulate the reservoir system to determine the reservoir releases required to maximize power at NyM hydro plant and those, which will favor storage conservation.

\subsection{Problem statement}

The Pangani River basin comprises one of the most important man-made regulating reservoir, the NyM. The reservoir is important for hydropower generation and irrigation schemes downstream. The operation of the hydropower system downstream the NyM depends on the releases from NyM. The main problem in the system is the insufficient power production due to insufficient water discharges reaching the turbines. The under performance of these plants has been a great loss to the nation, as the result of which the government owned TANESCO has been forced to introduce a power rationing especially during dry periods of the year.

The problem of inadequate water to run the turbines may be caused by (1) Decreasing inflows to the reservoir due to decreased precipitation upstream of NyM (2) Increased abstractions in the two reaches (Kikuletwa and Ruvu) feeding the reservoir, and (3) poor water release policies of the NyM reservoir. To have sufficient water for power production at $\mathrm{NyM}$, Hale and NPF, a study was conducted. This study looked into estimating the effective water quantities available for power production, and simulated different alternatives which determined releases from the NyM reservoir, that required maximizing the power production at NyM, as well as releases, which favor storage conservation in the reservoir. Several studies have been done in the NyM reservoir (Mulungu, 1997; Kilobe, 1998; Kigadye, 2000; Moges, 2003) but none used the HECResSIM model and did not consider abstractions upstream of the dam and options of storage conservation and hydropower optimization. Moges (2003) only compared operation policies of TANESCO and that recommended by NORPLAN. The conclusion was a combination of two policies for the best operation policy. Therefore, this study gives more options to deal with water management for NyM reservoir system.

\subsection{Objectives of the study}

The objectives of this research are to determine effective water reaching the Nyumba ya Mungu Reservoir and to perform reservoir system simulations. The simulations will enable to determine effective water releases from the reservoir that mainly (1) maximizes power production, and (2) favor both power production as well as water conservation within the reservoir.

\subsection{Description of the Area}

\subsubsection{Upper Pangani River basin hydrology}

The headwaters of the Pangani River are located in the Meru and Kilimanjaro Mountains which are the areas with substantial rainfall in Tanzania. Numerous streams from the Meru and Kilimanjaro mountains merge to form two major tributaries which are Kikuletwa and Ruvu that flows into the NyM reservoir. The 
Kikuletwa River collects runoff from watershed of Mt. Meru and southern slopes of Mt. Kilimanjaro, the main streams being Usa, Kware, Kikafu, Karanga and Weruweru rivers. A large part of flow for Kikuletwa is from Rundugai springs, which stabilizes the flow. The main flows for Ruvu comes from Kifaru River which drains water from Lake Jipe. The Lake Jipe is believed to be recharged by base flows through Lake Chala from the eastern part of Mt. Kilimanjaro and from North Pare Mountains. Other three rivers joining the Kifaru are Himo, Mue and $\mathrm{Rau}$ all originating from eastern part of Mt. Kilimanjaro. Figure 1 below shows a schematic of the river network just upstream the NyM reservoir.

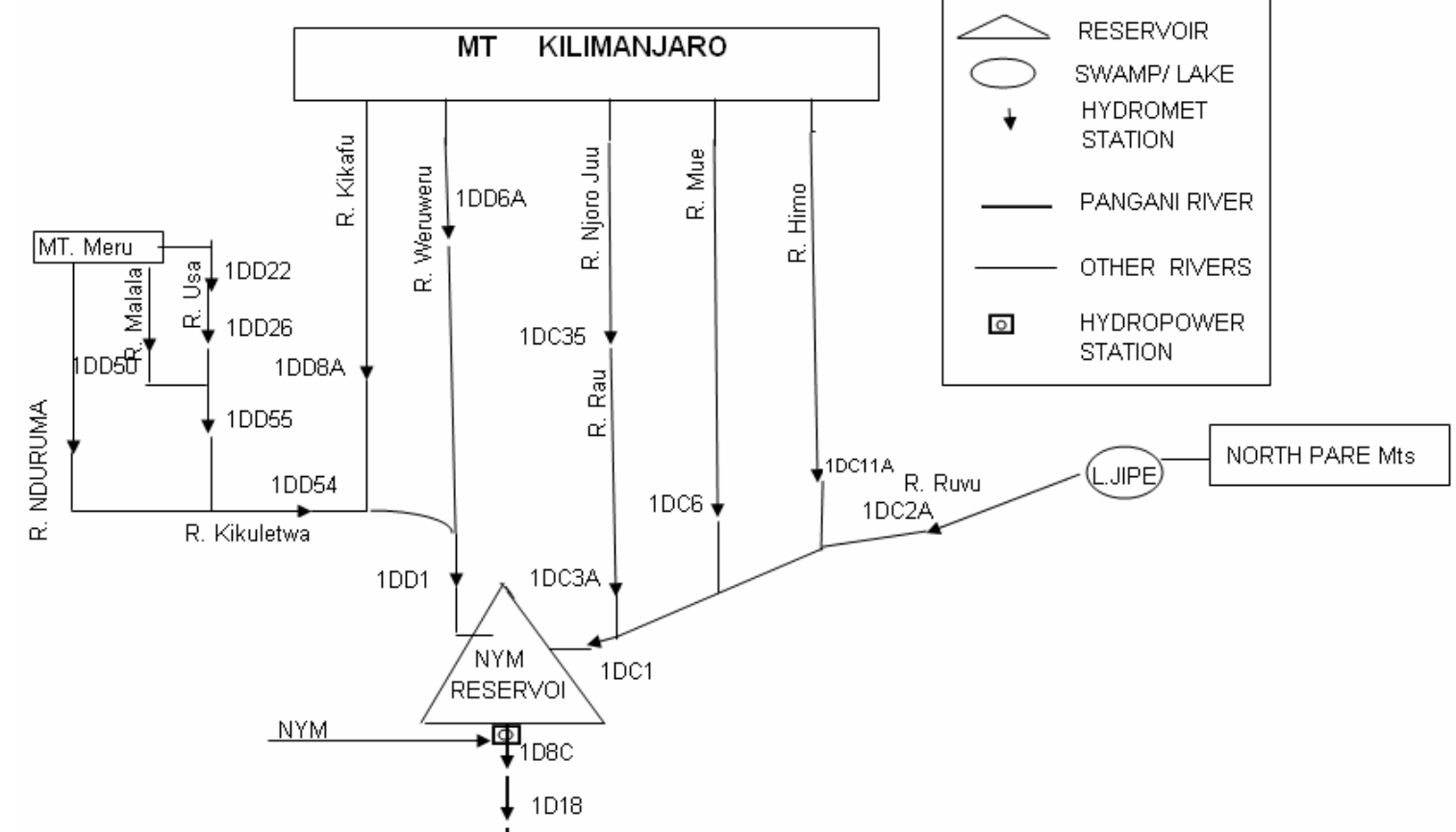

Fig. 1: Schematic of the Upper Pangani River catchment and the NyM reservoir

\subsubsection{Nyumba ya Mungu Reservoir features and drainage}

Nyumba ya Mungu Reservoir regulates upstream catchments having a total area of about $9000 \mathrm{~km}^{2}$. The spillway has a maximum design flood capacity of $920 \mathrm{~m}^{3} / \mathrm{s}$. The type of the dam is rock fill with maximum height of $43 \mathrm{~m}$ from foundation level. The dam fill volume is $480000 \mathrm{~m}^{3}$. The purpose of the reservoir was to store and regulate the Pangani River flow for both irrigation and hydropower generation downstream (Lein, 2004).

The reservoir catchment is drained by Kikuletwa River at gauging station (1DD1) and Ruvu River gauged at (1DC1). The reservoir receives water from the two main tributaries and just downstream

the reservoir, a small seasonal river called Lembeni joins the Pangani River. The discharge in the Pangani River varies throughout the year and within the reaches. The major factors influencing the discharge are the dry and wet seasons, and the altitude. Other influencing factors include evaporation loss and abstractions for irrigation. Generally, the runoff in Pangani Rivers is influenced by following phenomena:

Water from slopes of Kilimanjaro which can be snowmelt (thus providing a higher base flow throughout the year) or direct runoff from rainfall resulting into occasional peak flows.

Inflow from the dry savannah (climatic type), part of the catchment area downstream NyM reservoir.

\section{METHODOLOGY}

Several methods were used in analyzing the water balance components such as inflows from the gauging stations which involved the Galway River Flow Forecasting System (GFFS) in filling missing data at 1DC6, 1DC2A and 1DC11A (using the respective gauging stations on the upstream), water budget by the Nyumba ya Mungu Water Balance Model (NWBM) (Mulungu, 1997) and HECDSSvue in converting the inflows time series to the format that required by the HEC-ResSim model. 
The flows at those stations and at 1DD1, and rainfall over the reservoir were used to estimate inflows to the reservoir.

\subsection{Reservoir water balance computation}

For complete water balance of the reservoir, the following has to be considered; (1) inflows, (2) controlled and uncontrolled releases, (3) water losses such as evaporation, abstractions and seepages from the reservoir and (4) Rainfall contribution directly over the reservoir.

Unlike in Mulungu (1997), the inflows for water balance NWBM and HEC-ResSim models were estimated as sum of the flows at the gauging stations 1DC2A, 1DC6, 1DC11A and 1DD1, and the rainfall over the reservoir. The same method of summation was used by Moges (2003) and Perzyna (1994). Regarding the water loss component, the main factor considered to be more predominant are evaporation and water abstractions for irrigations activities. However, it is still difficult to quantify how much water usually escapes as abstraction component. This study considered abstractions taking place between the gauging stations upstream of the reservoir and the inflows entrance at the reservoir by utilizing the water balance approach and the HEC-ResSim. For the water balance approach in monthly time step and in volume terms, with the known releases from the reservoir and changes in reservoir storage, the unknown term in the water balance equation is the total loss. Then, abstractions were estimated by subtracting evaporation from the total loss. For the HECResSim model, abstractions were estimated by back simulation, applying scenarios of reduced inflows by percentages while observing the best fitting of observed water levels and releases in the reservoir system. In the model, evaporation was entered on monthly time step and distributed as equal values to number of days in a month. Other hydrological data and the simulations were on daily time step. In this context, abstractions was unaccounted for water and includes irrigation abstractions and the study did not deal with irrigation data per se. But, since the area between the gauging stations and the rim of the reservoir has small farmers practicing irrigation activities as cited by Kigadye (2000), then it was assumed that the unaccounted for water was mainly irrigation abstractions. Therefore, irrigation abstractions were considered to occur between the gauging stations 1DC2A, 1DC6, 1DC11A and 1DD1, and the inflows entrance to the reservoir. More details of the existence of irrigation activities and the HEC-ResSim model simulation can be found in Kigadye (2000) and Ngo'ndya (2006) respectively.

The potential evaporation from the reservoir was determined using Pan evaporimeters (Sunken pan Evaporation method) a factor of 0.7 was used to convert the pan readings presenting the actual evaporation in the water surface. Reservoir rating curves such as Elevation - storage curve and Elevation - area curve were used in the water balance computation in monthly time step. The Elevation - storage curve was very important for relating elevation to storages and the Elevation area curve was used when relating the reservoir evaporation and rainfalls into storages. Other curves such as spillway rating curve and controlled release rating curves were used by HEC-ResSim in reservoir simulation to compare simulated and observed outflows. The outflow is the total release flow from spills, turbines and bypass. The flow gauging station at $1 \mathrm{D} 8 \mathrm{C}$ was used for observed outflows.

\subsection{The HEC-ResSim model}

HEC-ResSim model (Klipsch, 2003) was designed to perform reservoir system simulation. It is intended to meet the needs of real-time reservoir regulators for a decision support tool, as well as the needs of modelers doing reservoir research studies. The HEC-ResSim was developed as successor to the "HEC-5, Simulation of Flood Control and Conservation Systems" program. HEC-ResSim is comprised of a graphical user interface (GUI), a computational program to simulate reservoir operation, data storage and management capabilities, and graphics and reporting facilities. The Data Storage System, HEC-DSS is used for storage and retrieval of input and output time-series data (Klipsch, 2003).

HEC-ResSim offers three separate sets of functions called Modules that provide access to specific types of data within a watershed. These modules are Watershed Setup, Reservoir Network, and Simulation. Each module has a unique purpose as explained below.

The purpose of the Watershed Setup module is to provide a common framework for watershed creation and definition among different modeling applications. This module is currently common to HEC-ResSim. A watershed is associated with a geographic region for which multiple models and area coverage can be configured. A watershed may include all of the streams, projects (e.g., reservoirs, 
levees), gauge locations, impact areas, time-series locations, hydrologic and hydraulic data for a specific area. All of these details together once configured form a watershed framework. In the Watershed Setup module, items that describe a watershed's physical arrangement are assembled. Once a new watershed has been created, then can import maps from external sources, specify the units of measure for viewing the watershed, add layers containing additional information about the watershed, then create a common stream alignment, and configure elements.

The purpose of the Reservoir Network module is to isolate the development of the reservoir model from the output analysis. In the Reservoir Network module, river schematic will be built to describe the physical and operational elements of the reservoir model, and develop the alternatives that are required to be analyzed. Using configurations that are created in the Watershed Setup module as a template, then required to create the basis of a reservoir network. Routing reaches are added and possibly other network elements to complete the connectivity of the network schematic. Once the schematic is complete, physical and operational data for each network element are defined. Also, alternatives are created that specify the reservoir network, operation set(s), initial conditions, and assignment of DSS pathnames (time-series mapping).

The purpose of the Simulation module is to isolate output analysis from the model development process. Once the reservoir model is complete and the alternatives have been defined, the Simulation module is used to configure the simulation. The computations are performed and results are viewed within the Simulation module. When creating a simulation then following must specified; a simulation time window, a computation interval, and the alternatives to be analyzed. Then, HECResSim creates a directory structure within the rss folder of the watershed that represents the "simulation". Within this "simulation" tree will be a copy of the watershed, including only those files needed by the selected alternatives. Also created in the simulation, is a DSS file called simulation.dss, which will ultimately contain all the DSS records that represent the input and output for the selected alternatives. Additionally, elements can be edited and saved for subsequent simulations.

\subsection{HEC-ResSim set-up for NyM reservoir}

In setting up the HEC-ResSim model for NyM reservoir, the three modules were attended. In the watershed module, the physical and important features such as the Digital Elevation Model (DEM), spillway rating curve, controlled release rating curve, elevation-storage-area rating curve, operation rules were collected and input to the model. In the network module, the river and reservoir were derived from the DEM, and the location of the gauging stations were entered and then the model interface schematized the reaches from the gauging station to reservoir. Other physical data entered included the spillway length and width at the crest, reservoir's lowest water level and highest water level, maximum spillway capacity, type of dam, length of crest and storage at highest water level. Hydrological data entered included rainfall and evaporation from $\mathrm{NyM}$ meteorological station, and reservoir water levels. Operational data entered included controlled outlet rating curves, spillway rating curves, operation policies and reservoir rating curve. This was then followed by system simulation in a daily time step.

\section{Results and discussion}

\subsection{Reservoir inflows estimation by summation}

Table 1 shows a list of the gauging stations and the period of available data used in this study, which is concurrent with the acquired hydropower generation data. 
Table 1: List of gauging stations near the NyM reservoir

\begin{tabular}{|l|l|l|l|}
\hline Position & Station code & Location name of the station & Record period \\
\hline \multirow{4}{*}{$\begin{array}{l}\text { Upstream the NyM } \\
\text { Reservoir }\end{array}$} & 1DD1 & Kikuletwa River near TPC & $1995-2005$ \\
\cline { 2 - 4 } & 1DC2A & Kifaru River at Tanga Road Bridge & $1995-2005$ \\
\cline { 2 - 4 } & 1DC3A & Rau River at Kahe forest & $1971-1982$ \\
\cline { 2 - 4 } & 1DC6 & Mue River at Kahe /Taveta Road & $1995-2005$ \\
\cline { 2 - 4 } & 1DC11A & Himo River at Moshi/Tanga Bridge & $1971-1982$ \\
\hline $\begin{array}{l}\text { Downstream the } \\
\text { NyM Reservoir }\end{array}$ & 1D8C & Pangani River at NyM & $1995-2005$ \\
\hline
\end{tabular}

Inflows to the reservoir were determined using the gauging stations: 1DD1, 1DC2A, 1DC6 and 1DC11A. The flows at these gauging stations are the measured one but immediately downstream there are several irrigation abstraction points ranging from legal to illegal abstractions. The people living in this area use water to irrigate maize, beans and paddy farms especially during dry period. Sometimes it is normal to see water flowing at the gauging station and a few meters downstream there is no water. This was observed during site visit in Himo River, which is one of the tributary of the main Ruvu River. Table 2 presents flows' basic statistics of the tributaries of Ruvu River and the estimated ones at $1 \mathrm{DC} 1$, a gauging station near the reservoir, which was abandoned following backwater effects after reservoir construction. As a rough estimate, the Ruvu River flows at 1DC1 may be considered as part of total inflows to the reservoir in addition to the Kikuletwa River (Table 3).

Table 2: Estimated mean discharges at 1DC1 for the period 1991-2005

\begin{tabular}{|c|c|c|c|c|}
\hline Station code & Mean $\left(\mathrm{m}^{3} / \mathrm{s}\right)$ & Std. dev. $\left(\mathrm{m}^{3} / \mathrm{s}\right)$ & $\begin{array}{c}\text { Max. } \\
\left(\mathrm{m}^{3} / \mathrm{s}\right)\end{array}$ & Min. $\left(\mathrm{m}^{3} / \mathrm{s}\right)$ \\
\hline 1DC2A & 6.42 & 3.40 & 29.28 & 2.82 \\
\hline 1DC6 & 2.83 & 2.10 & 43.43 & 0.02 \\
\hline 1DC11A & 2.55 & 3.60 & 45.88 & 0.00 \\
\hline Total flow at 1DC1 & 11.80 & 6.80 & 64.40 & 3.75 \\
\hline
\end{tabular}

Table 3: Mean discharge at 1DD1 and 1DC1 for the period $1991-2005$

\begin{tabular}{|c|c|c|c|c|}
\hline River & Mean $\left(\mathrm{m}^{3} / \mathrm{s}\right)$ & Std. dev. $\left(\mathrm{m}^{3} / \mathrm{s}\right)$ & Max. $\left(\mathrm{m}^{3} / \mathrm{s}\right)$ & Min. $\left(\mathrm{m}^{3} / \mathrm{s}\right)$ \\
\hline 1DD1-Kikuletwa & 24.00 & 21.50 & 220.89 & 8.20 \\
\hline 1DC1- Ruvu & 11.80 & 6.80 & 64.40 & 3.75 \\
\hline Inflow expected at NyM & 35.80 & 25.40 & 243.6 & 16.7 \\
\hline
\end{tabular}

Table 3 shows the total inflows expected to reach the NyM Reservoir as measured at 1DD1 and estimated at $1 \mathrm{DC} 1$ gauging stations. It showed from the Table that the Kikuletwa River has a high contribution on the water entering the NyM Reservoir. It contributes about $67 \%$ of the total inflow to the Reservoir. As a result of sources and sinks on the reservoir storage volume, there are Reservoir Water Level (RWL) variations. Figure 2 shows the observed reservoir water levels for the period 1995 - 2005. 


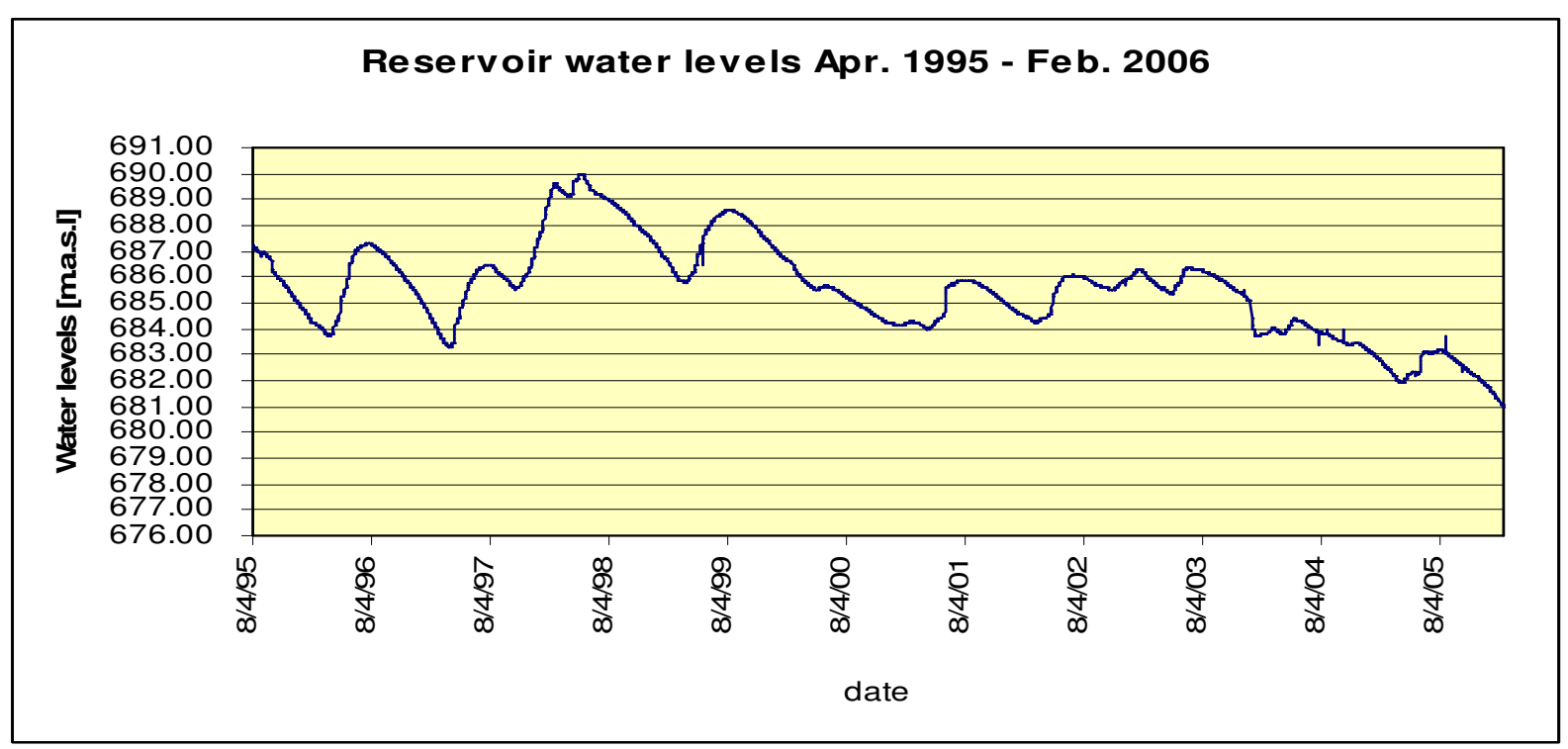

Fig. 2: NyM Reservoir water levels from 1995 to 2005

\subsection{Water abstractions and effective inflows estimation by HEC-ResSim}

As explained in section 2.1, water abstractions for irrigation were considered to occur between the gauging stations 1DD1, 1DC6, 1DC11A and 1DC2A and the entrance to the reservoir. Table 4 shows the remaining water (effective water) that reaches the reservoir after being affected by abstractions as estimated by HEC-ResSim model. The results from the model using scenarios of reduced inflows time series in Table 3 for the period $1995-2005$ showed that, only $73 \%$ of the inflow measured at the gauging stations (1DD1, 1DC6, 1DC11A and 1DC2A) reached the reservoir. The values in columns 4 and 5 in Table 4 were then obtained by applying a factor of 0.73 to the corresponding values in Table 3 . The remaining 27\% was lost from the Kikuletwa and Ruvu Rivers due to irrigation activities allowed along the rivers. Therefore, the water that reaches the reservoir after abstraction is on average $26.13 \mathrm{~m}^{3} / \mathrm{s}$. This value is close to the value $24.93 \mathrm{~m}^{3} / \mathrm{s}$ that was measured by Teale and Gillman (1935) in the dry season of $1934 / 35$ at $\mathrm{NyM}$ as reported by Lein (2004). Therefore, it was considered that the inflow estimates and the method used for estimation in this study were reasonably accurate. From the field visit done by the second author, it was found that the irrigation activities rendered the rivers either dry or to flow very low, which can be assumed to be similar to the dry season flows.
Table 4: Estimated effective mean inflows into the reservoir for the period 1991-2005

\begin{tabular}{|l|l|l|l|}
\hline River & $\begin{array}{l}\text { Mean } \\
\left(\mathrm{m}^{3} / \mathrm{s}\right)\end{array}$ & $\begin{array}{l}\text { Max. } \\
\left(\mathrm{m}^{3} / \mathrm{s}\right)\end{array}$ & $\begin{array}{l}\text { Min. } \\
\left(\mathrm{m}^{3} / \mathrm{s}\right)\end{array}$ \\
\hline $\begin{array}{l}\text { Kikuletwa at } \\
\text { 1DD1 }\end{array}$ & 17.52 & 161.25 & 5.99 \\
\hline Ruvu at 1DC1 & 8.61 & 47.01 & 2.74 \\
\hline $\begin{array}{l}\text { Total Inflow to } \\
\text { NyM }\end{array}$ & 26.13 & 177.83 & 12.19 \\
\hline
\end{tabular}

Analyzing the water balance from the results of HEC-ResSim model, total amount of the water found to escape from the system through evaporation was $240.08 \mathrm{Mm}^{3} / \mathrm{yr}$. This amount subtracts the effective inflows to the reservoir $\left(824.0 \mathrm{Mm}^{3} / \mathrm{yr}\right)$, whereas the rainfall contribution summed to $84.5 \mathrm{Mm}^{3} / \mathrm{yr}$ which adds to the effective inflows. The balance is what was available for power production from the reservoir (Fig. 3). Analyzing the observed release, which passes through the turbine, the long term average release discharges was $20.0 \mathrm{~m}^{3} / \mathrm{s}\left(630.7 \mathrm{Mm}^{3} / \mathrm{yr}\right)$. The water available for power generation is the water, which was not routed in the reservoir. The NWBM approach gave $698.5 \mathrm{Mm}^{3} / \mathrm{yr}$ as water available for power generation. These results show a small difference when compared to the HEC-ResSim simulated effective release of $657.62 \mathrm{Mm}^{3} / \mathrm{yr}$. This shows that the HEC-ResSim estimates were comparable and reasonable. Figure 3 summarizes the results from the NWBM and the HEC-ResSim approaches. 


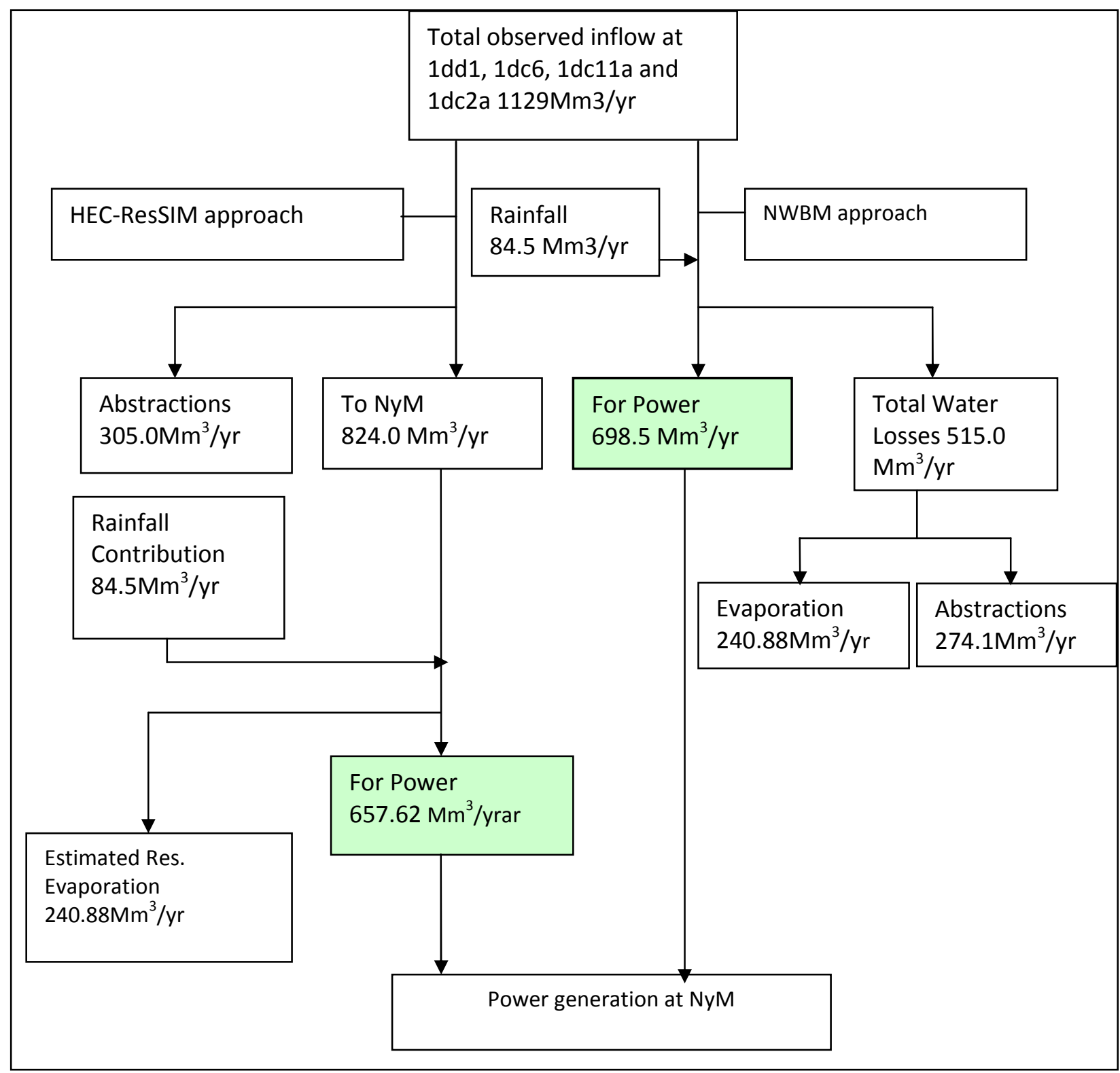

Fig. 3: Effective water available for power production

\subsection{Hydropower simulations}

The simulated releases from $\mathrm{NyM}$ reservoir by HEC-ResSim model were then used to determine the power achievable from the NyM hydro power plant. Among the two alternatives, it was observed that, with maximization option (utilizing whatever is available in the reservoir) power trends were found to peak up only within first 4 years of the simulation period. Thereafter, the RWL was maintained close to the recommended operational Lowest Water Level (LWL) (Fig. 4). At this LWL, power production only depends on inflows to the reservoir.
Power production was observed to drop down, which is technically true that the production of power at NyM reservoir depends on the heads maintained from water levels in the reservoir (Fig. 4). On the other hand, other functions of the reservoir were affected. For instance, low water levels affected other economical activities such as fishing and allocation for irrigation utilities downstream the reservoir. Moreover, there is an effect of environmental conservation, which affects the ecology. No spillages were noticed in this alternative. 


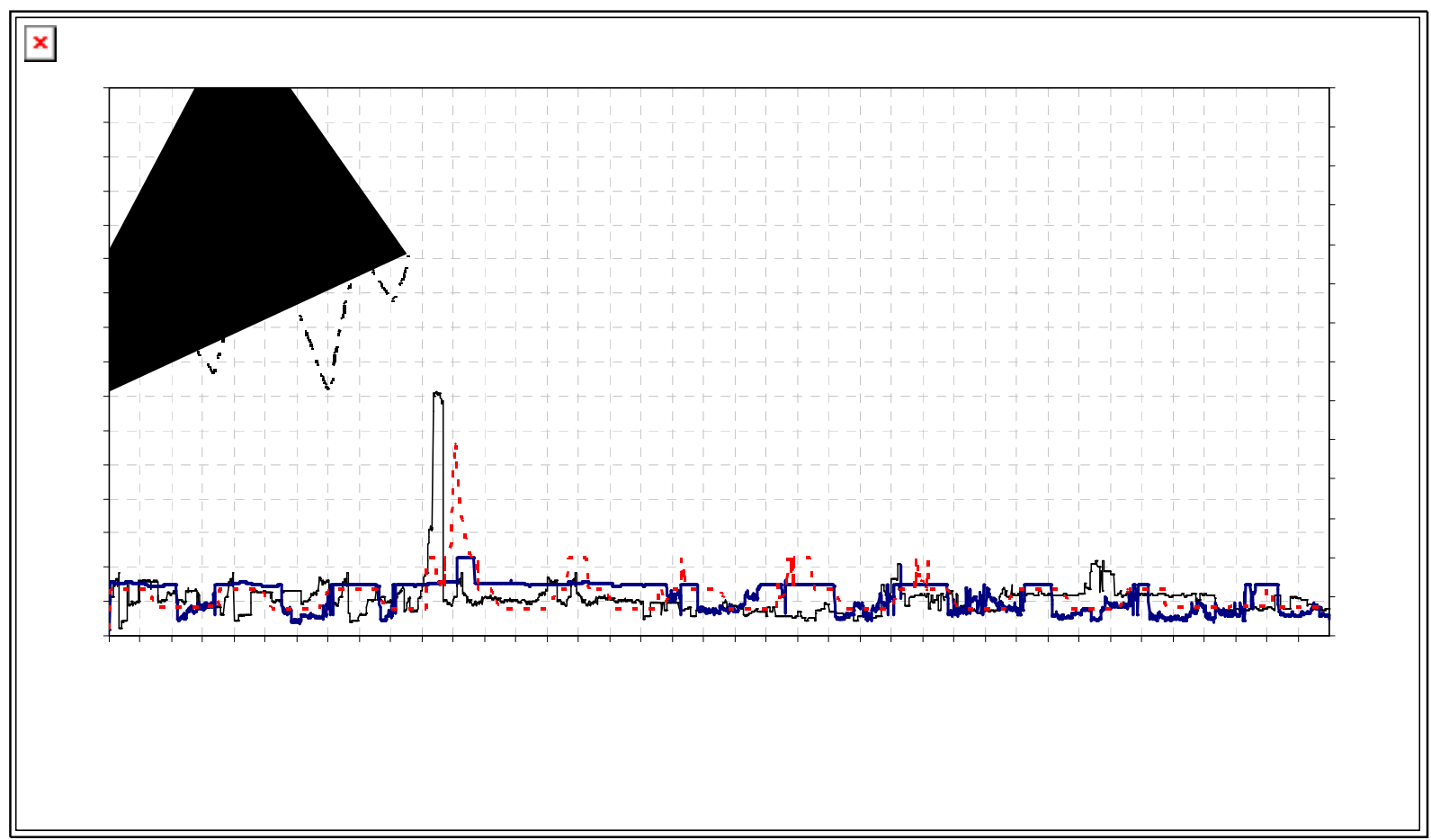

Fig. 4: Simulated release and reservoir water levels for NyM reservoir

The second alternative (storage conservation) of reservoir operation took into consideration of other functions of the reservoir as well as power production. In this alternative fishing activities were favored by keeping the reservoir water levels on higher side (Fig. 4). This also indicated that the power production was maintained nearly average throughout the year and this allows other functions of the reservoir to be accommodated effectively.

\subsubsection{Hydropower simulations with abstractions}

With maximization alternative, power production in 1998 and 1999 (turbines run near full capacity of 70 $\mathrm{GWh} / \mathrm{yr}$, obtained by as a product $8 \mathrm{MW} \times 24 \mathrm{x}$
365), and in 2001 and 2002 (turbines run below full capacity) exceeded the firm power $(47 \mathrm{GWh} / \mathrm{yr})$ (Kigadye, 2000) expected from NyM plant (Table 5), without spillage (Fig. 3.2). For the storage conservation, firm power was achieved in 1998 and 2001 with spillage in the former year. Comparing with the actual production operated by TANESCO, the same was achieved in 1998 (with much spillage), 2003 and 2004, when the plant was run below full capacity (Table 5, Fig. 4 and Fig. 5). Therefore, the storage conservation alternative minimized the spillages as compared to the observed ones and favoured integrated functions of the reservoir.

Table 5: Hydropower simulations with abstractions

\begin{tabular}{|l|l|l|l|}
\hline Year & $\begin{array}{l}\text { Maximization option energy } \\
\text { (GWh /year) }\end{array}$ & $\begin{array}{l}\text { Conservation option energy } \\
\text { (GWh/year) }\end{array}$ & $\begin{array}{l}\text { Observed energy } \\
\text { (GWh/year) }\end{array}$ \\
\hline 1996 & 48.24 & 42.94 & 43.41 \\
\hline 1997 & 46.52 & 44.00 & 42.70 \\
\hline 1998 & 63.94 & 52.37 & 48.44 \\
\hline 1999 & 61.64 & 46.49 & 46.23 \\
\hline 2000 & 45.35 & 45.61 & 31.97 \\
\hline 2001 & 49.09 & 47.73 & 25.83 \\
\hline 2002 & 48.35 & 45.07 & 41.88 \\
\hline 2003 & 37.57 & 44.00 & 49.75 \\
\hline 2004 & 32.52 & 41.98 & 51.23 \\
\hline 2005 & 36.43 & 36.12 & 35.15 \\
\hline Average & 46.97 & 44.63 & 41.66 \\
\hline
\end{tabular}


The average simulated power in maximization alternative was $46.97 \mathrm{GWh} / \mathrm{yr}$ and $44.63 \mathrm{GWh} / \mathrm{yr}$ in the conservational alternative. The two simulations are observed to have $13 \%$ and $7 \%$ respectively above the observed (TANESCO) production of $41.66 \mathrm{GWh} / \mathrm{yr}$.

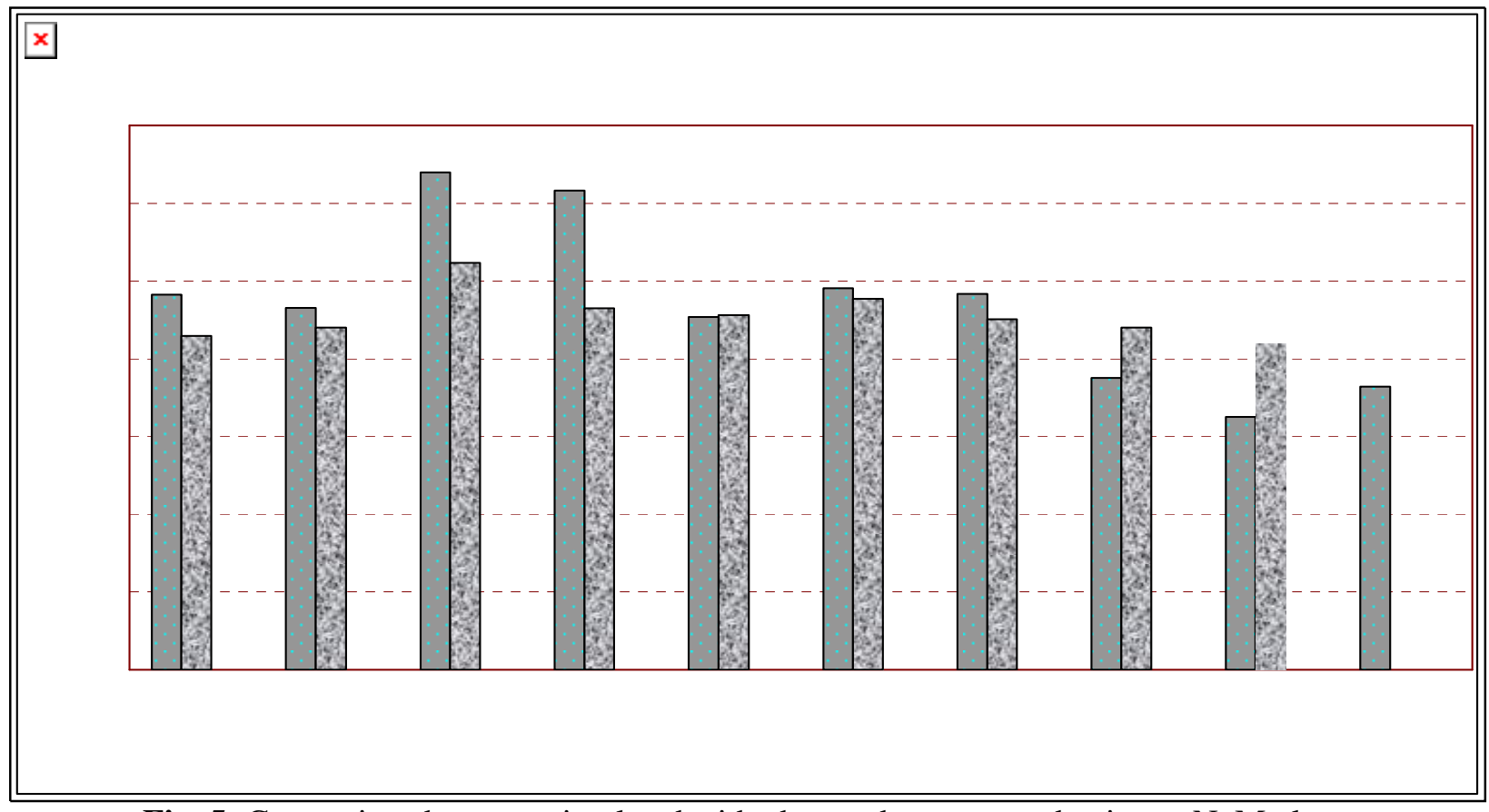

Fig. 5: Comparison between simulated with observed energy production at NyM plant.

Further analysis was done to the two alternatives. The developed duration curves for simulated power production are clearly indicated in Fig. 6, which shows the sustainability of power in hourly rated from both of the two simulated alternatives. The hourly rating was based on daily averages. At least more than $50 \%$ of the operation time, the maximization option was seen to generate above 6.5 MW. And the rest of the time there was a dramatic fall in power generation. In the conservation option, about $39 \%$ of operation time, the power generation was viewed to be close to $6.5 \mathrm{MW}$ and with a gentle drop, which then stabilized close to 4 MW during the rest of the operation time.

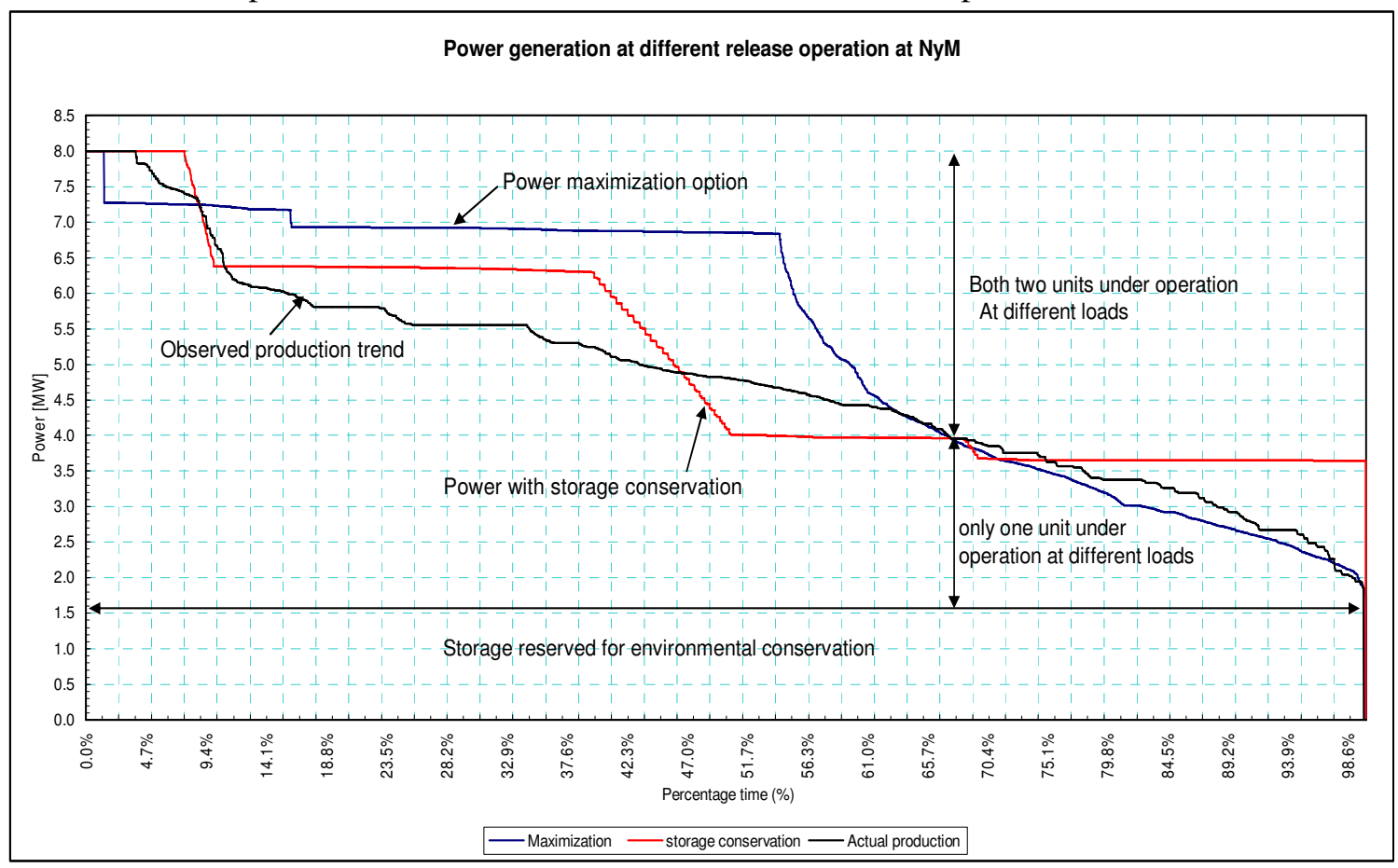

Fig. 6: Duration curve for simulated power generation at NyM hydro plant 


\subsubsection{Hydropower simulation without abstractions}

The simulation was also done with the assumption that the inflows measured at the gauging station are reaching the reservoir and therefore there is no abstractions taking place within the reaches before the reservoir. Table 6 shows a summary of the power obtained when there are no abstractions practiced along the reach. The increased energy is obtained after subtracting the energy with consideration to abstractions.

Table 6: Hydropower simulations without abstractions

\begin{tabular}{|l|l|l|l|l|l|}
\hline \multicolumn{7}{|c|}{ Abstractions not accounted } \\
\hline Year & $\begin{array}{l}\text { Maximization } \\
\text { option energy } \\
(\mathrm{GWh} / \mathrm{yr})\end{array}$ & $\begin{array}{l}\text { Increased } \\
\text { energy } \\
(\mathrm{GWh} / \mathrm{yr})\end{array}$ & $\begin{array}{l}\text { Conservation } \\
\text { option energy } \\
(\mathrm{GWh} / \mathrm{yr})\end{array}$ & $\begin{array}{l}\text { Increased } \\
\text { energy } \\
(\mathrm{GWh} / \mathrm{yr})\end{array}$ & $\begin{array}{l}\text { Observed } \\
\text { energy } \\
(\mathrm{GWh} / \mathrm{yr})\end{array}$ \\
\hline 1996 & 62.11 & 13.87 & 55.81 & 12.87 & 43.41 \\
\hline 1997 & 59.53 & 13.01 & 58.00 & 14.00 & 42.70 \\
\hline 1998 & 65.23 & 1.29 & 63.27 & 10.90 & 48.44 \\
\hline 1999 & 64.21 & 2.57 & 59.92 & 13.43 & 46.23 \\
\hline 2000 & 63.42 & 18.07 & 58.26 & 12.65 & 31.97 \\
\hline 2001 & 63.06 & 13.97 & 59.43 & 11.70 & 25.83 \\
\hline 2002 & 61.45 & 13.10 & 58.09 & 13.02 & 41.88 \\
\hline 2003 & 55.06 & 17.49 & 56.20 & 12.20 & 49.75 \\
\hline 2004 & 42.82 & 10.30 & 44.13 & 2.15 & 51.23 \\
\hline 2005 & 47.45 & 11.02 & 46.04 & 9.92 & 35.15 \\
\hline Average & 58.43 & 11.47 & 55.92 & 11.28 & 41.66 \\
\hline
\end{tabular}

\subsubsection{Effect brought by abstractions}

Abstractions have a big effect on power production in the Pangani basin. The results from HEC-ResSim (sect. 3.2) show that $27 \%$ of water expected to reach the reservoir was found to be abstracted for rrigation purpose. From Tables 5 and 6, comparing power simulated with and without consideration to abstractions, there was a difference of about 11.5 GWh annually, which is about $24 \%$ of the expected production (firm power). This amount of power is considered as loss contributed from irrigation abstractions allowed just within a small portion of the two reaches (Ruvu at 1D2A, 1D6A and 1DC11A, and Kikuletwa at 1DD1) that makes a distance of about $10 \mathrm{~km}$ from the gauging stations to the reservoir entrance. The NyM plant contributes only $8 \%$ to the total power expected in Pangani basin ( $95 \mathrm{MW}$ ), which was computed as the sum of installed capacities of the plants in the basin. Therefore, this loss could make a difference if compared to the Pangani River system as a whole. Taking a simple comparison that if $8 \mathrm{MW}$ is equivalent to $11.5 \mathrm{GWh}$, then $95 \mathrm{MW}$ is equivalent to $136.56 \mathrm{GWh}$. Therefore, roughly the whole system was estimated to loose nearly $136.56 \mathrm{GWh}$ annually, which implies about 15.6 MW. This power is nearly the capacity of Hale plant (21 MW).

\section{CONCLUSIONS AND RECOMMENDATIONS}

The study showed that the reservoir simulation model HEC-ResSim produced results similar to the water balance without details of water losses in form of evaporation, seepage and unaccounted for water in the water balance. Preliminary simulations and analysis showed that water abstractions or unaccounted for water (mainly due to small scale irrigation abstractions) upstream the NyM and poor reservoir operation contributed to underperformance of the NyM power plant. Abstractions upstream the NyM reservoir reduced inflows by $27 \%$ thereby decreased annual power production by $11.5 \mathrm{GWh}$. Also, during 1998 - 2001 poor operations resulted into lowering of reservoir water levels, which affected firm power generation. The research recommended reservoir operation considering storage conservation, which is near the firm power for the same period and at the same time favouring integrated functions of the reservoir with very little spillage. However, other factors such as power demand in the national grid, multifunction of the turbines, might have contributed to the observed poor operation of the NyM reservoir. 


\section{REFERENCES}

Kigadye, P., (2000). Hydropower project in Pangani River. M.Sc. Dissertation at the Norwegian Institute of Technology, Norway.

Killingtveit, A., and Saelthun, N.R., (1995). Hydropower development Vol.7 (Hydrology), Norwegian Institute of Technology. Division of Hydraulic Engineering.

Kilobe, B., (1998). Water balance study of Nyumba ya Mungu reservoir and subcatchments upstream in Pangani river basin in Tanzania. M.Sc. Water Resources Engineering dissertation at the University of Dar es salaam, Tanzania.

Klipsch, J.D., (2003). Reservoir system simulation HEC-ResSim user manual version 2.0. US Army Corps of Engineer, Institute of Water Resources Hydrologic Engineering Centre pp. 426.

Lein, H., (2004). Managing the water of Kilimanjaro: Irrigation, peasants and hydropower development. GeoJournal 61: 155-162.

Mhita, M.S, (2001). Development of methodologies for the utilization of seasonal climate prediction for forecasting hydropower generation (Tanzania) Tanzania

Perzyna, J.G., (1994). Assessment of inflow to Nyumba ya Mungu Reservoir, Tanzania. NORPLAN A/S.
Meteorological Agency (TMA), Project Supported by NOAA/OGP/CSI and USAIDOFDA.

www.ogp.noaa.gov/mpe/csi/esd/fundproj.htm Accessed: 24th September 2007.

Moges, S.A., (2003). Development and application of hydrological decision support tools Pangani River basin in Tanzania. Ph.D. Thesis, Water Resources Engineering at the University of Dar es salaam, Tanzania.

Mulungu, D.M.M., (1997). Application of linear models for inflow forecasting to Nyumba ya Mungu reservoir in Pangani River basin in Tanzania. M.Sc. Water Resources Engineering dissertation at the University of Dar es Salaam, Tanzania.

Ngo'ndya, R., (2006). Nyumba ya Mungu reservoir system simulation by using HEC-ResSim model in Pangani River basin in Tanzania. M.Sc. Water Resources Engineering dissertation at the University of Dar es Salaam, Tanzania.

Pabari, M., (2004). Dialogues Towards Sustainable Water Management in Pangani Basin Tanzania. IUCN Eastern Africa Regional Office (IUCN-EARO). www.iucn.org/programme/eval/database/regio n/global/2004/dialogues-sustain-watermgmt.pdf. Accessed: 24th September 2007.

Teal, E.O., and Gillman, C., (1935). Report on the investigation of the proper control of water: in the Northern Province of Tanganyika Territory, 1934. Government Printer, Dar es Salaam. 